\title{
UMA ANTROPOLOGIA TRAÇADA PELA PAIXÃO
}

Luiz Assunção

É isso que eu peço à ciência: que me faça apaixonar.

Mia Couto

O presente memorial é uma versão resumida do texto apresentado em novembro de 2014 ao Centro de Ciências Humanas, Letras e Artes da UFRN como parte dos requisitos para a ascensão à classe de professor titular na carreira do magistério superior ${ }^{1}$.

Ao escrever este memorial fui conduzido pela concepção de que o conhecimento- $\mathrm{o}$ aprender a pensar e conceber o mundo - se constrói em processo, vivido nas diversas experiências do mundo sensível e intelectual e na relação com o outro. Ao dar importância à experiência vivida, ressalto fases de minha vida, pessoas, eventos, como uma espécie de matéria que se coloca à minha disposição para, numa estratégia de bricolagem, ir compondo meu pensamento e conhecimento. Os primeiros ensinamentos aprendidos no núcleo familiar impregnaram-se no meu inconsciente e, ao somarem-se a tantos outros ensinamentos na escola, no cotidiano social, no trabalho, foram tatuando meu corpo e minha existência.

O relato sobre a história vivida descarta qualquer possibilidade de pensá-la como coerente e totalizante, como se estivesse organizada em uma sequência ordenada de acontecimentos. Ao contrário, o relato de vida depende das relações existentes na produção dos discursos, o que significa considerar o contexto no qual a história se desenrola e o conjunto das relações objetivas que uniram o agente considerado ao conjunto dos outros agentes envolvidos no mesmo campo e confrontados com o mesmo espaço possíveis. (BOURDIEU, 1996). Dessa forma, quero destacar que, ao tratar de histórias de vida, o olhar deve sempre ser analisado considerando-se o lugar ocupado pelo sujeito no interior do grupo e das relações mantidas com outros meios.

Gostaria, ainda, de ressaltar que, na elaboração de pensar e repensar o passado, estabeleci alguns marcos para a rememoração, através de linhas cronológicas, que teceram e vieram a compor o texto elaborado. Na primeira, que poderia chamar de linha histórica, assinalei os eventos significativos de processos históricos mais abrangentes, e também aquelas situações vividas particularmente por minha pessoa nesses contextos históricos abrangentes e que dizem respeito especificamente ao meu cotidiano e à minha circulação por diferentes esferas do social. Na segunda linha, apresentei os eventos que marcaram minha ação profissional a partir e no interior da vida acadêmica. No conjunto, procurei reunir os momentos mais marcantes do que, de fato, constitui o objeto central deste memorial, que é minha trajetória intelectual e acadêmica. 


\section{OS PRIMEIROS PASSOS - EXPERIÊNCIAS PLURAIS}

Aos seis anos de idade, tenho o primeiro contato com a escola. Foi a primeira experiência em grupo fora do meu universo de família e parentesco, onde acontecia minha socialização e aprendizado do mundo. Na pequena turma formada por doze alunos, que compunha o denominado "jardim de infância” do Grupo Escolar Querubina Silveira, uma escola pública da rede estadual de ensino, na cidade de Cerro Corá-RN, experimentamos a descoberta das letras do alfabeto, a junção dos fonemas, a composição das sílabas na formação de palavras, os números e suas possibilidade, mas também diferentes atividades marcadas pelo lúdico, através dos jogos, leituras, o desenho, a pintura, a música, todas experimentadas como possibilidades de elaboração do conhecimento formal e o estabelecimento de relações em grupo.

Ao mesmo tempo em que iniciava no ensino formal, minha mãe foi gradativamente me encaminhando para outras atividades complementares, de modo que, para além dos momentos recreativos, meus dias eram ocupados com aulas diversas, como a de reforço dos conteúdos estudados e, obrigatoriamente, o ensino de caligrafia. Aos sete anos de idade ganhei de presente um instrumento musical - um acordeão, e um professor foi incumbido de transmitir as primeiras noções musicais. Em outro momento, lembro-me da descoberta das cores e do cheiro das tintas nas aulas de pintura.

A intensa motivação que recebia na escola era igualmente vivida no universo familiar. Meus pais nunca perderam o contato com os parentes e seus territórios geográficos. Lembro-me das muitas viagens que fizemos aos sítios e propriedades rurais dos parentes que continuavam vivendo na zona rural de Santana do Matos, principalmente no período de colheita, nas festas de padroeiro, nas festas juninas, mas também nos velórios, quando todos da família se encontravam.

Existiam também as viagens para as cidades grandes, como Currais Novos e Natal, para visitar os parentes, resolver algum problema, geralmente relacionado à saúde ou fazer compras. Nessas viagens estava sempre acompanhando minha mãe e nessas idas e vindas por entre lugares aparentemente diferentes e desconhecidos, fui descobrindo contextos sociais diversos - um mundo rural, um mundo urbano, a tradição, a novidade. O novo e a novidade aparecem em minha vida como descobertas de imagens construídas no entorno social, que muitas vezes ganham forma em objetos concretos. Sempre tive a sensação de que, como cosmovisão, as ideias de tradição e a modernidade sempre coexistiram no pensamento dos meus pais e perpassam a dinâmica do meu universo familiar.

$\mathrm{Na}$ volta dessas viagens sempre ganhava um livro de presente que, de certa forma, materializava minhas andanças, inclusive aquelas imaginárias por mundos desconhecidos ${ }^{2}$. Sem ter a consciência da ideia da universalidade da cultura, minha mãe criava a oportunidade para que eu descobrisse novas conexões na elaboração do pensamento.

Muitas outras lembranças povoam minha infância na pequena Cerro Corá dos anos de 1960, como aquelas noites na residência de seu João Barbeiro, um pequeno agricultor e barbeiro, amigo dos meus pais, que juntava toda sua família para debulhar o feijão verde, contando intermináveis "estórias de trancoso" de mundos desconhecidos e misteriosos que me encantavam. Outros intensos encantamentos foram vivenciados. Não era raro aportar um circo na cidade e, quando isso acontecia, era dia de festa, melhor dizendo, eram semanas de alegria, riso, deslumbramento frente aquele mundo mágico. Gostava dos 
palhaços e suas piadas; gostava de ver as acrobacias, as dançarinas rumbeiras e os dramas dos teatros apresentados.

Para completar, gostava de andar entre as muitas barracas arrumadas no mercado em dia de feira. Observava as cores das miudezas expostas sobre as bancas, os diferentes produtos e, entre eles, vez por outra, aparecia uma novidade que chamava atenção, seja pela estética ou inovação tecnológica, como óculos esportivos ou o radinho de pilha. Era possível perceber como aquele espaço não era apenas comercial, mas também local de encontros e sociabilidades. Foi em uma dessas caminhadas pela feira que descobri uma nova possibilidade de leitura - a revista impressa e fiquei completamente atraído por aquele objeto. $\mathrm{O}$ vendedor colocava uma lona no chão e sobre ela arrumava as revistas, de modo que de longe dava para ver as letras das capas e os coloridos das imagens. Passei a ser frequentador e, acredito que, por eu ser conhecido, o vendedor permitia que folheasse todas as revistas. Esse foi o primeiro espaço de leitura que frequentei para consulta e leitura.

No início de 1968, presto o exame de admissão no Instituto Vivaldo Pereira, escola estadual recém-criada em Currais Novos, onde irei cursar o nível ginasial (1968-1971). Essa escola era ampla e organizada, com seus equipamentos modernos, contando também com uma equipe de professores qualificados. Todavia, apesar dessa aparente qualidade da estrutura escolar, a sociedade estava vivendo um contexto marcado por um Estado militar repressivo e sua ideologia desenvolvimentista, cujas ações também chegavam àquela escola encravada no sertão potiguar por intermédio da ausência de biblioteca e o incentivo à leitura, uma prática pedagógica bancária, conforme argumenta Freire (1982), pelo projeto de uma escola profissional - no caso, um ginásio com prática industrial, descartando qualquer possibilidade de uma escola com formação humanística. Comparando com a experiência vivida anteriormente na escola do nível primário, o ginásio era frio e impessoal, tinha mudado radicalmente o modelo de escola.

Eu já não era mais um garoto e precisava seguir. Assim como aqueles anos da infância deixaram marcas na minha formação, a década de 1970 vai representar o rompimento com o núcleo familiar, a possibilidade de transgredir, ousar e experimentar a construção de minha própria trajetória. Em janeiro de 1972, com dezesseis anos de idade, venho morar em Natal com o objetivo de dar continuidade aos meus estudos e trabalhar. $\mathrm{O}$ trabalho representava forma de sobrevivência e logo compreendi que também era caminho para a autonomia e independência. Durante o dia, trabalhava como auxiliar em um escritório de contabilidade, possibilitando aprender o senso de administração e organização. No horário noturno, frequentava o nível científico no Colégio Estadual Winston Churchill.

Esse é também um tempo de descoberta da cidade grande e, principalmente, da repressão promovida pelo Estado brasileiro. Foi nessa época que conheci Salinézio Oliveira. Ele trabalhava como educador no Movimento de Educação de Base - MEB, órgão da Arquidiocese de Natal, e, simultaneamente, coordenava o movimento político conhecido como Juventude Operária Católica - JOC, uma ação que acontecia principalmente junto a grupos de jovens localizados em bairros populares. A perspectiva de pensar a religião pelo viés político sistematizava o ato reflexivo e criava uma atitude em relação ao mundo e ao contexto sócio-político brasileiro. Integrei-me ao grupo e durante dois anos seguidos (1974-1975) acompanhei a equipe nos encontros coletivos que aconteciam por diferentes bairros da cidade, participando da organização, discussões e encaminhamentos. Embora o movimento não possuísse mais a vitalidade de antes, da minha iniciante participação, aprendi mais do que foi possível contribuir. Ali esbocei pela primeira vez um ensaio sobre a existência de diferenças 
de classes sociais e da compreensão do processo histórico de sua construção. Os ideários de justiça social e fraternidade compartilhada naqueles encontros ganharam forma em minha pessoa. Experimentei a imersão em outro mundo social e, ao voltar, estava impregnado desse espírito; não era mais o mesmo. Vivi uma relação com o mundo que é antes de tudo sensível, perceptiva, conforme expressa o pensador Merleau-Ponty (1994). Segundo o autor, experiência e conhecimento se entrelaçam no fenômeno da percepção e são fundamentais para, no ato do vivido, a elaboração de um entendimento.

\section{POR CAMINHOS ABERTOS}

Em dezembro de 1975 fiz vestibular para a Faculdade de Sociologia e Política, escola mantida pelo Governo do Estado do RN através da Fundação José Augusto. Era uma faculdade pública com ótima reputação na cidade. Além do curso de Sociologia e Política, a Fundação mantinha também o curso de Jornalismo. Os meus pais provavelmente não entenderam minha escolha e, principalmente, o que iria fazer após a conclusão. Eu, porém, ao fazer a escolha não tinha dúvidas que esse seria o caminho profissional, embora imaginasse que o caminho seria difícil. Aquele foi o último vestibular realizado por aquela instituição de ensino, uma vez que o acordo firmado entre as instâncias estadual e federal encerrava as atividades da conhecida faculdade, transferindo, no início do primeiro semestre de 1976, todos os alunos para o recém-criado curso de bacharelado em Ciências Sociais ${ }^{3}$ da Universidade Federal do Rio Grande do Norte-UFRN.

A frustrada possibilidade de frequentar um espaço onde pulsavam ideias e discussões foi dando lugar a um sentimento de orgulho pela inserção numa reconhecida instituição de ensino que iniciava seu projeto de crescimento. A sociedade brasileira ainda vivia um contexto de repressão e medo, e não foi por acaso o fechamento da antiga Faculdade de Sociologia e Política. A política do Estado brasileiro para o ensino e, especificamente, para o nível universitário, implantava um amplo processo de reforma de sua estrutura (curricular, organização política, aspectos físicos, etc.), refletindo diretamente no processo de ensino-aprendizagem e formação profissional.

O Departamento de Estudos Sociais englobava diferentes cursos com um quadro docente de graduados que, em geral, não demonstravam sensibilidade ou interesses para determinadas disciplinas como, por exemplo, antropologia. Existiam exceções, entre as quais estavam alguns cursos de sociologia, que particularmente me empolgaram. Apesar da presença de alunos militares em sala de aula e do material didático adotado, que seguia o modelo dos compêndios de orientação norte-americana, um ou outro professor conseguia romper o cerco repressivo e nos apontava questões sociais importantes.

O grupo de alunos que compunha a minha sala era predominantemente formado por pessoas adultas portadoras de um diploma de graduação ou que não tinham um diploma, mas estava inserida no mercado de trabalho. De uma forma ou de outra, tinham feito o vestibular de Sociologia para complementar a formação. Entre essas pessoas estava a assistente social Lourdinha Guerra, coordenadora estadual do Mobral, órgão do Ministério da Educação no estado do $\mathrm{RN}$, que, ao final do primeiro ano de curso, formaliza um convite de trabalho naquela instituição. A surpresa e expectativa deu lugar à concretização do desejo de trabalhar em uma atividade mais próxima do curso escolhido. Estava com 21 anos de idade e muitos sonhos. Pedi demissão do emprego no escritório de contabilidade em que estava há cinco anos. Antes de assumir no serviço público, preparei uma mochila e, na mesma noite, peguei um ônibus na rodoviária da 
Ribeira e parti, "sem lenço e sem documento", para minha primeira viagem de descoberta do Brasil. Nem imaginava que ainda estavam por vir as viagens de descoberta das veredas do Sertão. Durante um mês andei por Salvador, da Bahia; Ouro Preto, as cidades históricas mineiras; e a velha capital do Rio de Janeiro, em um roteiro de conhecimento do patrimônio histórico e cultural brasileiro. Também da percepção das diferenças regionais; de uma visão de Brasil como "uma terra de contrastes" (BASTIDE, 1978), apesar da promoção feita pelo governo militar de um "pra frente Brasil", desenvolvido e integrado.

O Mobral ${ }^{4}$ foi para mim uma grande viagem; como encontrar outros mundos na minha própria terra, outras viagens, outros sujeitos. Em meio as muitas estratégias de ação, dias de estudos eram realizados, seja para pensar sobre os procedimentos de alfabetização ou realizar leituras discursivas. Foi nessa época que conheci alguns livros de Paulo Freire, notadamente "Pedagogia do oprimido" (FREIRE, 1982), paradoxalmente obra de referência para os técnicos daquela instituição. Os iniciantes, como eu, no processo educativo, passavam por um período de treinamento, inclusive acompanhando os pedagogos nas reuniões de comunidade e nas salas de aula com os alunos-professores formadores. Depois de certo tempo é que poderíamos assumir a responsabilidade de condução do trabalho de campo. Assim, vivenciei minha primeira experiência de sala de aula assumindo um treinamento para professores da região do Seridó em um fim de semana na cidade de Acari - RN.

O trabalho no Mobral me levou a viajar por todo o estado do Rio Grande do Norte, do litoral à região oeste, passando pela região do Sertão do Seridó, proporcionando a percepção das diferenças regionais e questões rurais e urbanas. Durante quase um ano e meio de trabalho, oportunizei com a prática profissional a reflexão sobre o mundo social que a sala de aula, no curso de Ciências Sociais, não tinha condições de oferecer. Procurava estabelecer relações das situações concretas de vida - as dificuldades de reprodução das condições materiais de existência dos pequenos agricultores, a relação com a terra; as condições socioeconômicas dos moradores das periferias urbanas, o mandonismo político local, por exemplo, com os conteúdos abstratos trabalhados em algumas disciplinas, delineando o meu interesse pelo campo da sociologia e antropologia.

Poderia ter ficado um pouco mais vivendo a rica experiência do Mobral. Porém, estava no segundo ano de faculdade, sem orientação acadêmica, numa estrutura de ensino que reproduzia um modelo autoritário de educação e sozinho construía meu próprio caminho. $\mathrm{O}$ intensivo trabalho e a necessidade das permanentes viagens a campo obrigaram-me a decidir pelo afastamento, uma vez que tinha colocado como prioridade a conclusão do curso de graduação. Assim, ao demitir-me da estabilidade de um emprego federal, a saída foi participar da oportunidade que aquele momento apontava - a seleção como estagiário no Serviço Social do Comércio - SESC.

A condição de bolsista de estágio no setor de estatística do SESC (1978) durou menos de um semestre, uma vez que fui convidado para ocupar uma vaga como funcionário no setor de educação, ficando na instituição pelos próximos cinco anos, ao longo dos quais fui assumindo diferentes funções: chefe do setor de educação, diretor da divisão de orientação social e assessor da direção regional. A oportunidade de aprender e colocar em prática uma série de atividades relacionadas ao processo de planejamento e coordenação talvez tenha sido a principal herança desse período de trabalho.

Ainda durante o curso de graduação tive a oportunidade de conhecer o professor Veríssimo de Melo, conhecido na cidade pelos livros publicados na temática do folclore e que viria a ser diretor do Museu Câmara Cascudo. Professor Veríssimo convidou-me para participar de sua equipe de pesquisadores, 
formada por alguns poucos alunos. Como tinha um contrato trabalhista que me tomava a maior parte do tempo, não pude aceitar o convite. Nessa época não existia na Universidade uma estrutura organizacional de pesquisa, nem tampouco um programa de distribuição de bolsas para alunos, de modo que a pesquisa era uma atividade muito particular, iniciativa individual do professor. Apesar de não ter participado do seu grupo de alunos, mantinha sempre contato com ele e algumas vezes levava um trabalho final de disciplina para que ele pudesse avaliar. Um desses trabalhos, aquele feito para a disciplina cultura popular, em que discorria sobre o processo de produção e circulação do artesanato santeiro de dona Teodora, artesã do município de Acari, valeu-me um comentário avaliativo por escrito. Dele ganhei alguns dos seus livros, sempre autografados. Conhecer o professor Veríssimo, tomar conhecimento e ler alguns dos seus escritos fortaleceram meu interesse pelos estudos do folclore e da cultura popular e, o que considero como mais importante, também me instigou a buscar outros autores que escreviam sobre a temática, entre os quais acabei me apaixonando pela obra dos potiguares Manuel Rodrigues de Melo e Oswaldo Lamartine de Faria.

Em 1979, frequentando o último ano do curso de Ciências Sociais, experimento a que considero sua melhor fase, a que corresponde à chegada dos professores visitantes contratados pela Universidade para executarem o projeto de criação de uma pós-graduação em antropologia ${ }^{5}$.

Naquele último ano de faculdade, o estímulo recebido de um grupo de professores me fez esboçar ensaios sobre o tema dos chamados pequenos proprietários rurais, caracterizados como aqueles que detêm a posse legal da terra e que trabalham, geralmente, com a mão de obra familiar, basicamente através de uma cultura de subsistência. As questões que me moviam estavam relacionadas à busca por compreender a relação do trabalhador com a terra, o processo de produção e expropriação rural, as relações de trabalho no meio rural, entre outras questões. Na época, a discussão sobre campesinato estava bastante intensa em decorrência da produção acadêmica nos cursos de pós-graduação, abarcando temas como o trabalho familiar de pequenos produtores rurais, a agricultura marginal à plantation açucareira no nordeste brasileiro, os planos de ação governamental para a agricultura e barragens, como as estratégias de sobrevivência dos camponeses ${ }^{6}$.

O interesse pelo tema rural e as questões relacionadas às condições de existência social dos pequenos agricultores, somando-se às leituras acumuladas sobre a temática, levaram-me a elaborar uma proposta de pesquisa, submetendo-a à seleção do Programa de Pós-Graduação em Antropologia Social da UFRN. No ano de 1979, em que concluía o curso de graduação, a UFRN implantava o referido curso de pós-graduação e, no início do ano seguinte, aprovado no processo de seleção, iniciava meu primeiro semestre letivo.

É claro que, à medida que ia fazendo as disciplinas no curso de mestrado ${ }^{7}$ e conhecendo outros referenciais, o projeto inicial foi se transformando. Existia certo clima de efervescência na Universidade, proporcionado pelo contexto de abertura política do Estado brasileiro. O materialismo histórico e o pensamento marxista nas ciências humanas eram estudados e discutidos em sala de aula. A vertente marxista da antropologia francesa, formada com um grupo de estudiosos que incluía Georges Balandier, Maurice Godelier, Claude Meillassoux, entre outros, era trabalhada na disciplina Antropologia das sociedades camponesas, e, recebida por nós, mestrandos, como outra possibilidade teórica para pensar os estudos da cultura. A esse conjunto teórico somavam-se leituras mais aprofundadas de alguns textos clássicos de Claude Lévi-Strauss sobre o pensamento selvagem e as estruturas elementares de parentesco. 
Ao concluir as disciplinas-créditos no mestrado de antropologia social, dediquei-me a algumas leituras de trabalhos produzidos em cursos de pós-graduação sobre o tema do campesinato e a pequena agricultura familiar. Entre eles, um em especial me chamou atenção: a dissertação de mestrado de Margarida Maria Moura (1978), "Os herdeiros da terra: parentesco e herança numa área rural".

Outro trabalho que me foi muito caro foi o de Nazira Vargas (1987), "História que o povo conta", uma tentativa de construir a história do oprimido a partir da sua própria percepção da opressão e dos mecanismos de resistência por ele articulados diante dela. A pesquisa tinha como objeto de estudo as condições de produção e reprodução social de um campesinato localizado nas Ribeiras do Piranhas-Açu, no estado do RN, em um contexto em que a população vivenciava um processo de perda de suas terras em decorrência da construção de uma barragem. Embora o estudo fosse conduzido por um denso referencial teórico, o que particularmente vai me chamar atenção é o processo metodológico da pesquisa e a percepção de uma nova forma de abordar e experimentar a observação participante, em que o camponês ribeirinho se transformava em um interlocutor. $\mathrm{O}$ que faz a diferença não é o fato de a pesquisadora residir na área por longo período, mas da perspectiva metodológica assumida (VARGAS, 1987).

As questões e reflexões apresentadas por Moura (1978) sobre reprodução camponesa e relações de parentesco, ou seja, pensar o grupo familiar como dotado de uma dinâmica, com uma organização de produção, de consumo e de reprodução que emerge de um processo histórico, me levou a pensar especificamente em um grupo - os negros do Riacho, comunidade negra rural localizada no município de Currais Novos.

No início dos anos de 1980, quando decidi estudar os negros do Riacho praticamente nada existia escrito sobre eles ou qualquer outra comunidade negra no estado, exceto as referências feitas pelos historiadores nomeando as comunidades negras e, no caso do Riacho, uma reportagem jornalística publicada em um jornal local em que apresentava dados gerais e ressaltava o caráter de isolamento do grupo. Portanto, percebi que tinha um campo completamente aberto para ser explorado como pesquisa.

Ao definir o campo empírico da pesquisa, outras questões surgiram: como tratar de um grupo negro em um mundo rural branco? Ou como pensar as relações entre brancos e negros na sociedade brasileira? Sobre o tema das relações raciais no Brasil, uma vasta e significativa produção bibliográfica estava disponível e, à medida que me dedicava a essas leituras, outra vereda foi se formando, levando-me especificamente para o tema das "comunidades negras rurais" (Pereira, 1981). Essa abordagem de estudos estava em foco no âmbito da antropologia da Universidade de São Paulo, principalmente pelo professor João Batista Borges Pereira, em que dão ênfase ao tema das populações negras em condições rurais, camponeses negros. Esses estudos seguiam um referencial teórico-metodológico centrado na ideia de tratar as comunidades negras como bairro rural, entendida como uma estrutura mínima de sociabilidade, através do agrupamento de família, vinculadas pelo sentimento de localidade, pela convivência, pelas práticas de auxílio mútuo e pelas atividades lúdico-religiosas. (CÂNDIDO, 2001).

A ebulição do processo de conhecimento que vivenciava não correspondia ao contexto enfrentado pelo Programa de Pós-Graduação em Antropologia da UFRN que, diante do seu desmantelamento institucional, transformando-o em Programa de Pós-Graduação em Ciências Sociais, e a não permanência de antropólogos em seu quadro, produziu concretamente o fato da não existência 
de orientador para o tema. Diante do impasse e da certeza do tema escolhido, resolvo solicitar o trancamento do curso, só retornando alguns meses depois.

Ao solicitar o retorno ao curso com o objetivo de conclui-lo, tinha escrito uma proposta de dissertação e a indicação de um nome para orientador, o professor Luiz Eduardo Soares, na época recém-incorporado à equipe de antropologia da UNICAMP. As leituras realizadas foram delineando o que viria a ser a dissertação, cujo fio condutor era a disputa travada entre parentes pelo direito de propriedades das terras do Riacho e outros conflitos daí decorrentes, vividos na prática diária por seus moradores, os "caboclos" e os "negros". Ao final, a pesquisa mostrou que um grupo aparentemente fechado, coeso e homogêneo era, na realidade, um grupo conflitante, estratificado e envolvido numa rede de relações sociais e políticas, sem, todavia, deixar de ser um grupo, dotado de representações identitárias, o que é, em si mesmo, significativo. Assim, em os "Negros do Riacho", procurei descrever seu modo de vida, a luta pela terra, as estratégias econômicas e sociais de sobrevivência, as alianças e o sistema interno de liderança e poder, com o objetivo de "procurar perceber como, na trajetória de suas vidas, a identidade social é elaborada e representada por essas pessoas e qual o sentido dessa identidade no contexto da história do grupo". (ASSUNÇÃO, 2009a, p. 17).

A perspectiva inicial de pensar a concepção de "comunidade negra rural" como um "bairro rural" foi substituída pelos conceitos de grupo e identidade, tal como usados nos estudos da antropologia no campo das relações interétnicas nas sociedades complexas (CARDOSO DE OLIVEIRA, 1976), que procurava explicar processos e consequências de contatos de sociedades tribais brasileiras com sociedades regionais inclusivas. Assim, recorri às análises feitas pelo autor em estudos sobre diferentes grupos étnicos e procurei compreender a identidade étnica - no caso não associada a uma sociedade tribal - como um modo de representação social. Outra referência que orientou conceitualmente o trabalho foi a teoria das fronteiras étnicas de Fredrik Barth (1976) nos princípios de abordagem em que enfatiza o caráter relacional e situacional das relações sociais e suas fronteiras.

\section{UNIVERSIDADE FEDERAL DO RIO GRANDE DO NORTE, OFÍCIO OU PAIXÃO}

A oportunidade de ingressar na universidade surgiu no início de 1982, quando o edital para preenchimento de uma vaga de professor assistente para a disciplina Sociologia no Centro Regional de Ensino Superior do Seridó UFRN, campus de Currais Novos, saiu publicado. A UFRN vivia uma fase de expansão caracterizada por uma política de interiorização da instituição. $\mathrm{O}$ concurso ocorre de imediato; consigo aprovação.

Assumir o cargo de professor na UFRN foi também um forte motivo para retomar o curso de mestrado, do qual estava afastado, conforme explicitei no tópico anterior, elaborando estratégias para a sua conclusão ${ }^{8}$. Trabalho parte dos dados das pesquisas citadas e apresento meus primeiros escritos, publicando-os em jornais locais. $\mathrm{O}$ artigo "As estratégias de sobrevivência de um grupo negro", publicado no jornal Dois Pontos (Natal, 1989), ganha uma página do jornal e divulga pela primeira vez o resultado da pesquisa na comunidade dos Negros do Riacho.

Semanalmente, me deslocava para o município de Currais Novos, a fim de cumprir com minhas obrigações docentes, sem deixar de assumir também atividades em Natal. Permaneci como docente do campus de Currais Novos 
pelo período de oito anos (1983-1991). Ao final desse período, aquela unidade de ensino passava por uma crise estrutural, afetando sua existência através do fechamento de alguns cursos, como o de Estudos Sociais e História. Nesse contexto, solicitei minha remoção para o Departamento de Ciências Sociais (Campus de Natal). Em contrapartida, o Departamento de Ciências Sociais emitiu um documento em que propunha minha transferência através da sessão de vaga. É importante destacar que, desde a conclusão do mestrado (1988), semestralmente vinha assumindo uma disciplina de antropologia no Departamento de Ciências Sociais, como também participando das reuniões departamentais e demais atividades acadêmicas, o que significa dizer que exercia regularmente funções nas duas unidades de ensino.

Com a minha transferência para o Departamento de Ciências Sociais, assumo a Coordenação do curso de graduação (1992-1994), com a incumbência, entre outras atividades, de proceder a uma nova reforma curricular, seguida da implantação do sistema de informatização na dinâmica administrativa e burocrática. Assumir o cargo de coordenador de curso no campus central possibilitou um conhecimento mais detalhado da estrutura da universidade, além de propiciar a circulação por diferentes setores da esfera administrativa. Desde então, venho participando plenamente das discussões pertinentes ao curso de graduação em Ciências Sociais (bacharelado e licenciatura), participando de comissões e ministrando disciplinas, como de várias outras atividades acadêmicas, seja ligada ao Departamento de Ciências Sociais, ao Departamento de Antropologia ou a outras instituições?.

\section{O CURSO DE DOUTORADO NA PUC, SÃO PAULO}

Em 1995 começo a pensar na possibilidade de cursar o doutorado. Minha proposta de tese tinha como foco as religiões afro-brasileiras, mais especificamente o catimbó-jurema, um campo de estudo praticamente desconhecido, situado em parte da região do Nordeste brasileiro. Estava interessado em compreender o culto da jurema e seus rituais. Submeto-me à seleção do Programa de Estudos Pós-Graduados em Ciências Sociais da PUC-SP pleiteando uma das vagas disponíveis para a professora doutora Josildeth Consorte.

No Programa de Ciências Sociais da PUC fiz os cursos obrigatórios (antropologia e seminário de pesquisa) e outros considerados optativos, realizados com os professores Maria Helena Vilas Boas Concone, Teresinha Bernardo, Ennio Brito e Jerusa Pires Ferreira. Com as duas primeiras, fiz praticamente todos os cursos exigidos no currículo, nos tornamos amigos e, no decorrer do processo, elas foram imprescindíveis, dialogando com as questões pertinentes à construção da tese. Uma das disciplinas cursadas com Maria Helena tinha como proposta fazer uma revisão da obra de Roger Bastide, momento em que reli alguns textos e procedi a novas leituras do autor. Se, por um lado, Bastide em seus estudos sobre as religiões afro-brasileiras ressalte a supremacia nagô ao reafirmar a oposição entre um candomblé nagô "autêntico" e uma macumba "degradada", em razão da pobreza mitológica dos bantos, por outro lado, suas pesquisas sobre o mundo banto revelam preciosas informações empíricas sobre as quais terei particular interesse. O curso dedicado à teoria da memória, uma leitura do pensamento de Henri Bergson e Maurice Halbwachs, realizado com a professora Teresinha Bernardo, apresentou-me outra base epistemológica, no campo do conhecimento, por meio de novas referências conceituais, como as noções de tempo e espaço para pensar o passado e o processo histórico. 
Mas não fiquei limitado ao Programa de Ciências Sociais. Tinha uma necessidade de buscar outros conhecimentos e poder usufruir o máximo possível do que Universidade pudesse oferecer. Nessas deliberadas fugas epistemológicas, atravesso os corredores dos Programas de Ciências da Religião e o de Comunicação e Semiótica e chego a outras salas de aula. No Programa de Religião, frequento os cursos do professor Ênio Brito e fico encantado com a perspectiva de pensar os cultos afro-brasileiros através de uma releitura da escravidão, propiciando uma compreensão das relações interétnicas e das estruturas simbólicas da experiência religiosa afro-brasileira, inclusive no mundo contemporâneo. Leio pesquisas realizadas sobre o tema, a partir de diferentes enfoques no próprio campo das ciências da religião, como na antropologia e sociologia, mas fundamental foi conhecer a reflexão historiográfica sobre a diáspora negra, os processos históricos de deslocamentos e construções identitárias no Atlântico negro.

No Programa de Comunicação e Semiótica, tomo conhecimento da reflexão semiótica sobre cultura a partir de diferentes perspectivas conceituais. Interesso-me pelo curso da professora Jerusa Pires Ferreira, dedicado aos estudos teóricos sobre culturas populares e literatura da voz, cuja ementa explicitava a pretensão de enfocar textos e conceitos fundantes para enfrentar o desafio de entender as culturas tradicionais, sua avaliação em continuum rumo a extensões transmidiáticas. Pessoalmente, tinha certeza da necessidade de compreender melhor a reflexão sobre o tema das culturas tradicionais, e acreditava ser esse um caminho para pensar especificamente meu campo empírico, ou seja, o culto do catimbó-jurema. Sabia do percurso inovador traçado pela professora Jerusa em suas pesquisas na temática das culturas populares. Desse modo, acreditava que aquele curso poderia render bons frutos na minha tese. Converso com a professora e frequento seu curso como ouvinte. $\mathrm{O}$ interesse inicial foi se transformando na descoberta de um campo de leituras completamente novo, deixando-me instigado. Pela primeira vez ouvi falar de pensadores como Eleazar Meletinski, Boris Schnaiderman, Iúre Lotman. No entanto, apaixonei-me por Paul Zumthor; foi amor ao primeiro livro. Ao ler "Introdução à poesia oral", fiquei impressionado com a dimensão antropológica do conceito de cultura que permeia o pensamento do autor, sua reflexão e análise. Durante um fim de semana, fiz a leitura completa do livro e nunca mais me separei dele, do livro e de Zumthor.

Como de certa forma já explicitei, minha ânsia de conhecimento não estava limitada à PUC, ao contrário, estava sempre circulando pelos eventos da cidade e por aqueles realizados na USP, em especial, os seminários organizados pelo professor Reginaldo Prandi. Uma de minhas referências nos estudos das religiões afro-brasileiras, conhecia sua produção bibliográfica, como também já estivera com ele em uma de suas visitas à UFRN. Numa dessas vindas a Natal, ele procurou-me para saber do campo religioso natalense. Na oportunidade, levei-o à casa de Babá Karol, o mais conhecido babalorixá da cidade ${ }^{10}$. Certo tempo mais tarde, em Salvador, a seu convite, participo de uma visita ao Ilê Opô Afonjá e de uma mesa redonda na Reunião Anual da SBPC, para a qual ele tinha convidado além de minha pessoa, os professores Ari Pedro Oro e Mundicarmo Ferretti. Desde aquele primeiro encontro, muitos outros aconteceram sempre permeados por instigantes projetos, como a publicação do livro "Encantaria brasileira". (PRANDI, 2001) e o documentário produzido pela TV Globo, "Êxtase, ritos sagrados - catimbó jurema". 


\section{AS VIAGENS ETNOGRÁFICAS DE MÁRIO DE ANDRADE E A MINHA VIAGEM DA "DESCOBERTA DO SERTÃO"}

Em minhas andanças durante o doutorado em terras paulistas, tomo conhecimento das viagens etnográficas do escritor paulista Mário de Andrade, sobretudo a Missão de Pesquisas Folclóricas, viagem idealizada por Andrade e enviada ao Nordeste brasileiro em 1938. O interesse do escritor pela contribuição que as culturas populares poderiam oferecer para a literatura no campo erudito segue as influências recebidas do movimento romântico europeu. Acreditava que o importante era buscar o entendimento da realidade brasileira em suas múltiplas diferenças, através do conhecimento do povo e de suas condições de vida, ou seja, a partir da cultura. A partir da pesquisa e do registro da produção popular, elabora uma literatura onde recria os elementos que vieram da narrativa oral, contribuindo para a construção do conceito de brasilidade e de uma imagem síntese da nacionalidade e cultura brasileiras. É no bojo dessa concepção que o escritor vai pensar a realização de viagens pelo interior brasileiro com objetivos etnográficos, denominando-as de viagens etnográficas.

Apesar de considerar o Norte-Nordeste como ricos repositórios de tradição e cultura popular, a primeira viagem etnográfica que organiza e realiza é para Minas Gerais, durante a Semana Santa de 1924, a denominada "viagem da descoberta do Brasil". Posteriormente, outras viagens vieram como a de 1927, tendo como destino as regiões norte e nordeste e Amazônia.

Em dezembro de 1928, Mário de Andrade viaja ao Nordeste na qualidade de correspondente do jornal Diário Nacional de São Paulo. Denominou-a de "viagem etnográfica do turista aprendiz". (ANDRADE, 1983), reafirmando, através da decisão de realizar uma pesquisa etnográfica, o seu interesse pela cultura do povo. Durante a viagem, realiza um trabalho intensivo de coleta de dados, principalmente nos estados da Paraíba e Rio Grande do Norte.

Após a segunda viagem que faz ao Nordeste, Mário de Andrade constatou a necessidade de voltar à região para efetuar coletas mais sistemáticas, com o objetivo de completar suas observações e notas para o planejado volume "Na pancada do ganzá". Todavia, impossibilitado de retornar ao Nordeste, diante dos compromissos assumidos no Departamento de Cultura da Prefeitura de São Paulo, canaliza a ideia para o planejamento de uma "viagem etnográfica", que deveria ser assumida institucionalmente pelo referido Departamento. Essa viagem, denominada de Missão de Pesquisas Folclóricas, expressará na prática o pensamento do escritor sobre pesquisa de campo e etnografia.

Apesar de ser o grande idealizador da Missão enviada ao Nordeste no período de fevereiro a julho de 1938, Mário de Andrade não participa da expedição, uma vez que acontecimentos políticos o impedem de retornar à região, porém procura acompanhar todos os passos da Missão, seja através dos relatórios, seja através da correspondência mantida com a equipe. A expedição é formada por quatro integrantes e percorre os estados de Pernambuco, Paraíba, Ceará, Piauí, Maranhão e Pará com o objetivo de realizar a coleta da música folclórica da região e documentá-la através de registro fotográfico e cinematográfico.

É obvio que, depois de todo esse movimento cognitivo, meu projeto de doutorado não era mais o mesmo; algo tinha mudado. As diferentes leituras que fiz, mas principalmente tomar conhecimento dos empreendimentos de pesquisa levados adiante pelo escritor Mário de Andrade, proceder à leitura da bibliografia produzida no âmbito das "viagens etnográficas" (relatórios, cartas, romances), como também realizar a leitura e consulta do acervo disponível da Missão de 
Pesquisas Folclóricas de 1938, em especial a documentação escrita e visual sobre o catimbó-jurema, foram fundamentais para proporcionar uma mudança significativa em meu projeto de doutorado, relativa aos aspectos empíricos, procedimentos de objetivos e conceitos. Tinha conhecimento da prática do catimbó-jurema nas cidades de Natal, João Pessoa e Recife, mas a constatação dessa prática, na década de 1930, em cidades do interior da Paraíba levou-me a interrogar sobre sua existência no presente e, mais importante, procurar compreender o catimbó-jurema como tradição e o processo de transmissão dessa tradição no contexto atual. Dizendo de outra forma, interessava-me compreender as transformações ocorridas na constituição do culto religioso, advindas de diferentes influências e de uma dinâmica que gerava uma nova prática de jurema (Assunção, 2006).

O primeiro passo foi elaborar um roteiro para o campo empírico da pesquisa de tese, seguindo aquele elaborado pela Missão, privilegiando o Sertão nordestino. Além da Missão, existia uma pista deixada por Roger Bastide, quando afirma que "há no Maranhão uma zona de transição entre a capital e o Sertão onde as religiões africanas estão misturadas com o catimbó, de origem indígena (...) chamados de encantados". (BASTIDE, 1989, p. 257). Mas não esqueci as referências descritas pela documentação histórica sobre a ocupação e o povoamento da região, que estabeleceu um caminho - o do gado -, e um espaço onde esses caminhos se encontravam - o Sertão das Piranhas. É nessa rota que se encontram os municípios com maior densidade populacional e mais urbanizados. Estava definido o campo de pesquisa que incluiu as cidades de Patos e Sousa (Paraíba), Iguatu e Juazeiro do Norte (Ceará), Picos (Piauí) e Salgueiro (Pernambuco).

Assim, inspirado em Mário de Andrade, parto para a minha grande viagem etnográfica, a viagem da "descoberta do Sertão". Na primeira fase do trabalho de campo (setembro a novembro de 1997), percorri todos os municípios citados e fiz contato com 29 casas de umbanda, quando realizei entrevistas abertas e exploratórias com os dirigentes das casas e outros participantes, como observei rituais públicos e privados. Ainda nessa fase, realizei um levantamento dos dados disponíveis nas fichas de inscrição dos sócios das Federações de Umbanda existentes nos municípios de Patos-PB, Juazeiro do Norte-CE e Picos-PI.

Em um segundo momento da pesquisa, realizado entre agosto de 1998 e janeiro de 1999, trabalhei com um número menor de casas religiosas, selecionadas a partir da análise dos dados colhidos na primeira fase da pesquisa, seguindo os objetivos delineados no projeto. Foram escolhidas duas casas: Afoxé de Oxum, em Patos-PB, e o Centro São Jorge Guerreiro, em Juazeiro do Norte-CE. O trabalho de campo, durante essa segunda fase, basicamente foi organizado pela realização de história oral de vida com os respectivos sacerdotes, observações dos rituais e demais atividades cotidianas.

A prática de dar voz aos sujeitos, compondo uma narrativa em que seja possível expressar suas experiências de vida, já estava presente em minha pesquisa anterior - a dos negros do Riacho; no entanto, a maturidade do pesquisador, associada a um conjunto de leituras, possibilitaram uma prática mais sistemática e consistente do ponto de vista qualitativo. Aprendi a escutar, ficar atento àquelas vozes que "fomos encorajados a deixar de ouvir" (Couto, 2005, p. 48). Aprendi a tornar essas vozes visíveis. Prática, aliás, que irei fazer presente nos trabalhos posteriores. Também aprendi a me colocar com clareza na relação com o outro, sempre adotando como procedimento, durante o trabalho de pesquisa, expor claramente os objetivos do meu trabalho e dizer quem sou, $o$ que faço e a que instituição estou ligado. Isso provavelmente contribuiu para o 
fortalecimento de relações e o meu envolvimento em um campo no qual gradativamente fui me incluindo como aliado e, como tal, passando a ser percebido.

O procedimento de leituras para uma abordagem teórico-metodológica da pesquisa foi acontecendo desde o início do curso de doutorado, mantendo-se durante sua fase de trabalho de campo. Essas leituras me fizeram retornar aos conceitos produzidos por uma antropologia interpretativa de Clifford Geertz (1978). A concepção interpretativa de cultura já estava presente em minha dissertação de mestrado, mas nessa fase do doutorado me dediquei a uma leitura detalhada do livro "A interpretação da cultura" (Geertz, 1978), assumindo o fio conceitual que norteia o trabalho ou em termos epistemológicos, como indica Hans-Georg Gadamer, a concepção de que qualquer compreensão é também interpretação. (GADAMER, 2012).

\section{DE VOLTA A UFRN}

Concluído o doutorado ${ }^{11}$, estava cheio de sonhos e tinha um débito com os juremeiros de Natal (e era constantemente cobrado por não escrever sobre a jurema natalense). É certo que havia ainda tanto o que pesquisar, tanto ainda sobre o que refletir; algumas das questões levantadas na tese solicitavam reflexões. No entanto, depois de quatro anos afastado da Universidade, ao retornar, em 1999, encontro meus colegas da equipe de antropologia envolvidos no processo de criação do Departamento de Antropologia. A criação do novo departamento, em 2000, para além de relocar a antiga equipe de antropologia existente no Departamento de Ciências Sociais, gerou em todos nós o compromisso em fortalecer a recém-criada unidade acadêmica ${ }^{12}$.

Outra ação que me envolvi de imediato foi a Pós-Graduação através do credenciamento no Programa de Ciências Sociais e, posteriormente, no de Antropologia Social, representa a construção de outras possibilidades de investimento no trabalho e em minha trajetória acadêmica. $\mathrm{O}$ trabalho de orientação é especial e vai sendo traçado lentamente, em um longo processo simultâneo de ensino e aprendizado que envolve professor-orientador e aluno-orientando. Todavia, a orientação nem sempre é fácil de ser conduzida. O tempo mínimo para conclusão do trabalho monográfico, principalmente nos níveis de graduação e mestrado, tem sido cada vez mais reduzido, trazendo dificuldades para o orientador conduzir adequadamente o processo. Por sua vez, os alunos têm dedicado pouco tempo às atividades de leitura e trabalho de campo, sem falar na ausência do conhecimento produzido em outras ciências, na filosofia, na literatura, nas artes, que de um modo geral contribui na formação do aluno.

Nesse processo de orientação, é possível observar o crescimento intelectual de alunos que têm como ponto de partida a iniciação científica ${ }^{13}$, através das primeiras noções de pesquisa, sistematização de leituras e a participação em eventos acadêmicos. Em geral, esses alunos dão continuidade aos seus estudos enveredando pela pós-graduação. Em relação à pós-graduação, alguns alunos sequenciaram, sob minha orientação, os níveis de mestrado e doutorado. Outros foram em busca de diferentes instituições de ensino, notadamente após o mestrado. De um modo geral, os ex-orientandos estão sempre retornando com pedidos de orientação ou informações, o que me faz acompanhar seus percursos ${ }^{14}$.

Dos trabalhos de orientação concluídos, na pós-graduação, alguns foram premiados em concursos promovidos por instituições governamentais:

Em casa de catiço: etnografia dos exus na Jurema, dissertação de Marcos Queiroz, premiada no Concurso Nacional de Pesquisa sobre Cultura 
Afro-Brasileira, Comunidades Tradicionais e Cultura Afro-Latina, no ano de 2010, pela Fundação Cultural Palmares e escolhida pelo colegiado do PPGAS-UFRN como a melhor dissertação de mestrado de 2008.

Os trabalhos de amor e outras mandingas: a experiência mágico-religiosa em terreiros de umbanda, dissertação de Kelson Oliveira, recebeu o Prêmio Guilherme Studart de Ensaio sobre tema cultural, no ano de 2010, pelo Governo do Estado do Ceará (Secretaria de Cultura).

As árvores me começam: o mundo por Manoel de Barros, tese de doutorado de Kelson Oliveira, selecionado pela Bolsa de Fomento à Literatura da Fundação Biblioteca Nacional e Ministério da Cultura (2014).

Em meio aos papéis da burocracia administrativa e a "corrida" pela produtividade acadêmica, tão importantes para os órgãos de fomento institucional acadêmico, brotaram com intensidade germes das reflexões plantadas durante o período de estudos em São Paulo, que dizem respeito ao movimento de construção da ciência e seus paradigmas, exigindo leituras. Assim, releio autores com a intenção de que eles me ajudem a pensar a ciência e uma atitude científica. Entre as leituras, nada mais impactante que o "fim das certezas" de Ilya Prigogine (1996) e sua concepção sobre os processos de não-equilíbrio. Ao fazer a revisão do conceito de tempo na física, Prigogine quebra a simetria entre passado e futuro que a física tradicional afirmava. Ao incorporar a noção de instabilidade, a significação das leis da natureza não mais se assenta em certezas, como as leis deterministas, mas exprimem possibilidades.

Volto a ler Mikhail Bakhtin $(1986,1992)$ e suas reflexões sobre cultura, enunciação, os gêneros do discurso e dialogismo. Suas contribuições para a teoria da linguagem ajudam a pensar a teoria antropológica da cultura, a temática da alteridade e a dimensão da pesquisa em antropologia. Não posso deixar de fazer referência à literatura disponível a partir dos chamados estudos pós-coloniais, em especial a contribuição de Stuart Hall (2003), Homi Bhabha (1998) e tantos outros que se dedicaram a repensar a cultura no meio de uma globalização complexa e contraditória, as dimensões político-culturais da globalização, a resistência aos discursos hegemônicos do poder colonial.

É nesse turbilhão de pensamentos epistemológicos que enveredo por um dos projetos mais fascinantes que tive o prazer de participar como escritor e integrante da comissão editorial - o Projeto Galante. O periódico criado pelo Projeto Nação Potiguar (Fundação Hélio Galvão - Natal, RN) circulou encartado no jornal Tribuna do Norte, uma vez por mês, no período de 1999 a 2007, numa tiragem média de 16.000 exemplares para cada número. Revestido por uma ideia de divulgação científica, o projeto continha em sua proposta provocar uma panorâmica significativa das manifestações populares locais, através de textos temáticos com enfoque antropológico, contemplando, ainda, uma concepção fotográfica e documental. Ao final, foram publicados 68 números, abarcando, entre outros, temas referentes às manifestações artísticas, folclóricas, festas religiosas e profanas, atividades de trabalho, devoções populares, como também conteúdos relacionados aos grupos étnicos indígenas, ciganos e quilombolas.

Logo após o término do Projeto Galante, mais exatamente em 2008, o convite da Fundação Cultural Capitania das Artes, órgão da Prefeitura Municipal de Natal, para coordenar o projeto de estudos de criação e implantação do Museu de Cultura Popular Djalma Maranhão, abiu um campo de trabalho na temática cultura e patrimônio. Uma equipe com profissionais das áreas de antropologia, folclore, museologia e arquitetura, foi formada com o objetivo de colocar em prática uma agenda de trabalho que incluía a elaboração de uma 
concepção conceitual, realização de estudos, acompanhamento das fases de execução e implantação final do museu.

\section{O FONDS DOCUMENTAIRE PAUL ZUMTHOR, UNIVERSITÉ DE MONTRÉAL, CANADÁ}

No segundo semestre de 2011, solicitei à UFRN uma licença-prêmio à qual tinha direito e fui para Montréal, Canadá. Há algum tempo vinha estabelecendo contatos com Éric Méchoulan, professor do Departamento de Literatura Francesa da Université de Montréal e diretor do Fonds Documentaire Paul Zumthor da mesma universidade. Encaminhei uma proposta de estudos a ser realizado no Fonds Zumthor, que foi aprovada pelo referido professor e que consistia em atividades de leitura de alguns textos de Paul Zumthor ${ }^{15}$, publicados em periódicos. Os textos, escritos em língua francesa e praticamente sem circulação no Brasil, se apresentavam, na minha perspectiva, inéditos que precisavam ser lidos para complementar e ajudar a compreender a formulação de conceitos trabalhados pelo autor no livro "Introdução à poesia oral". (ZUMTHOR, 1996).

Paul Zumthor, conhecido como medievalista, foi um estudioso das culturas. Nascido em Genebra, cresceu e foi educado em Paris. Docente, lecionou em universidades da Holanda, Estados Unidos e Canadá. Em sua primeira fase de estudos, dedica-se ao conhecimento da literatura medieval europeia e, posteriormente, retorna aos seus estudos do medievo, para buscar nos registros escritos da poesia medieval as marcas da voz viva, e lança-se à observação das suas manifestações contemporâneas.

Em seus estudos sobre os séculos X e XIV, observou um processo de trânsito vocal, socialização e transmissão do texto, no qual a palavra prática vocalmente transmitida, reatualizada, favorece a migração de mitos, de temas narrativos, de formas de linguagem, de estilos, etc., contribuindo para a manutenção do laço social, do imaginário e da autoridade. Esse modelo de circulação da palavra poética e da obra literária reforça, para o autor, o pensamento de que a voz foi um fator constitutivo de toda obra literária, ressaltando que ela se concretiza em sua transmissão, pela presença simultânea dos participantes dessa ação. Crítico da orientação limitada à análise do texto verbal e, ao expressar a noção de que a escrita é, de certo modo, fixa e de que nada se compara à força nômade da voz, desenvolve o que vai denominar de uma teoria da vocalidade. Ao enfocar a oralidade como um conceito de oralidade aberta e flexível, se concentra nos efeitos da presença, do ambiente e do corpo em ação. Para Jerusa Pires Ferreira, o medievalista "não recebia imposições de sistemas fechados, para ele tudo era experimentação e travessia. Se, de um lado, se concentrava sobre o núcleo da tradição cultural europeia, ao mesmo tempo conduzia sua atenção para a descoberta dos novos mundos, das novas modalidades de comunicação". (FERREIRA, 2007, p. 152).

O trabalho foi iniciado tomando conhecimento da relação do material disponível no acervo, seguido da escolha dos textos que deveriam ser lidos em sua totalidade, a partir de um critério geral que incluía a reflexão do autor sobre as poéticas da oralidade. Li e reli os textos escolhidos; sem pressa, apenas tentando compreender e estabelecer relações com o conhecimento que tinha sobre a teoria do autor. A leitura dos textos escolhidos levou-me a refazer a trama dos conceitos e a procurar entender as etapas de elaboração das ideias por meio dos escritos sobre voz e vocalidade; escritura e a voz; oralidade e escritura; circularidade e movência do texto. Entre as "descobertas", a percepção de como 
o autor vai elaborando, lentamente, seus conceitos e ideias, e que é possível acompanhar numa sequência de textos.

Considero que meu encontro com Paul Zumthor consolida minhas perspectivas epistêmicas teóricas e de pesquisa sobre a condição humana, a cultura e as diversidades simbólicas e espirituais das populações com as quais partilhei grande parte de minha vida, permitindo uma maior abertura para minha itinerância reflexiva como intelectual e pesquisador ${ }^{16}$.

\section{COMUNIDADES NEGRAS, QUILOMBOLAS, RELIGIÕES AFRO-BASILEIRAS}

A atividade de pesquisa foi sempre central em minha trajetória acadêmica. Sempre senti necessidade do campo empírico, do olhar e ouvir, do estabelecer contatos com diferentes sujeitos. Poder estudar uma sociedade, um grupo social ou um ritual religioso em seu contexto e, a partir dos dados coletados, desenvolver uma análise, uma reflexão ou uma descrição interpretativa, têm sido a atitude intelectual predominante ao longo de minha trajetória como antropólogo. As práticas sociais são as minhas principais fontes de informação e as categorias êmicas as bases de minhas reflexões. No campo da pesquisa, não tenho interesse apenas nos fatos e no material coletado para descrição interpretativa. No fundo, meu interesse principal é pelo modo como a população ou os grupos sociais subalternos enfrentam a adversidade, como reinventam um modo de viver e resistir ou, como adverte Stuart Hall (2003): como pensar de forma não reducionista as relações entre o social e o simbólico.

O meu interesse pela temática de pesquisa no campo de estudos das populações afro-brasileiras foi gestado, como aluno de pós-graduação, no contexto do curso de mestrado em antropologia social da UFRN, conforme descrevi anteriormente. Durante quase uma década, de 1980 a 1988, me dediquei à pesquisa e leitura sistemática sobre o tema hoje denominado de "comunidades quilombolas".

O convênio celebrado entre o INCRA e a UFRN ${ }^{17}$, em 2005, proporcionou voltar a pensar e trabalhar com o tema das comunidades negras rurais. O contexto era outro, pós-constituinte, e a perspectiva do enfoque tinha mudado. Tempo de construção de uma ordem política democrática, na qual os grupos minoritários e os movimentos sociais elaboravam uma agenda - a dos novos direitos, porque inseridos nas demandas cotidianas de setores amplos da população, como os direitos humanos e sociais. Agora, aquele mundo das comunidades negras rurais era pensado a partir de uma concepção de remanescentes de quilombos, embasada em perspectivas jurídica e política. Por outro lado, a proposta da elaboração de um laudo antropológico, objetivo principal do referido convênio, me colocava em uma posição especial, pensando na relação com a comunidade, uma vez que existia uma solicitação que partia da própria comunidade, ou seja, da Associação Quilombola dos Moradores do Jatobá (Patu-RN).

Durante o trabalho de campo, no decorrer do ano de 2006, convivi com todas as pessoas da comunidade do Jatobá. As constantes referências sobre o passado, que ganhavam forma através de nomes, datas, imagens, situações vividas, me levaram a privilegiar as narrativas orais e a pesquisa em arquivos institucionais, propiciando, a partir dos dados colhidos, refletir sobre o passado de uma família escrava e a diáspora vivida no processo pós-abolição. Assim, o campo de pesquisa se ampliava e chegava ao arquivo, utilizando-o como fonte 
de conhecimento para a produção de análises, mas também contribuindo para pensar o uso de fontes arquivísticas na pesquisa antropológica.

Em meio a milhares de papéis abandonados nos arquivos de igrejas e instituições públicas, foi indescritível a surpresa ao encontrar documentos de um tempo da escravidão, como registros de batizados, cartas de alforria, entre outros, pertencentes a membros da família do Jatobá. Lembro, em especial, de uma semana de trabalho intenso no arquivo do Fórum Municipal de Martins, quando, no segundo dia, encontrei a carta de alforria de Manoel, a referência mais antiga da família. Naquele momento, poderia ter concluído o trabalho, mas estava diante de uma riqueza documental que me deixava extasiado e resolvi continuar abrindo caixas empoeiradas e cheias de traças. Embora não soubesse o que poderia fazer com aqueles documentos, resolvi fazer cópia de alguns deles e, ao final, tinha um acervo do século XIX composto por livros de registro de cartas de liberdade e alforria, escrituras de compra e venda de escravos, escrituras de inventários de parentes dos proprietários de escravos relacionados com a família do Jatobá, além de três processos cíveis de liberdade ${ }^{18}$.

Para dar continuidade a esse relato sobre meu entrelaçamento com a pesquisa e o trabalho de campo, preciso voltar ao ano de 1988. Após a conclusão da pesquisa sobre os negros do Riacho e sua apresentação como dissertação de mestrado, vi-me tomado por alguns questionamentos, seja em torno da continuidade da temática ou, especificamente, sobre o que iria fazer em termos de pesquisa. O tempo que tinha disponível tornara-se um grande problema para administrar. Existia uma carga horária de sala de aula a ser cumprida, as viagens semanais para o expediente no campus da UFRN no interior, as aulas no campus central e nenhum apoio financeiro para investir em pesquisa. Decidira, então, pelo menos em caráter temporário, não dar continuidade à atividade de pesquisa com a temática das comunidades negras rurais.

No âmago desse meu contexto de dúvidas, aceitei participar do Projeto de estudo e catalogação do acervo afro-brasileiro do Museu Câmara Cascudo. Não tinha nenhuma vivência de pesquisa no campo das religiões afro-brasileiras. Na verdade, nunca tinha ido a um terreiro. A proposta do Museu, embora específica - o estudo do acervo material - indicava uma aproximação com $o$ campo das religiões afro-brasileiras em Natal.

Ao longo de um ano de pesquisa no projeto do acervo do museu, as visitas aos terreiros, às entrevistas realizadas com os sacerdotes e as observações dos rituais, me levaram a perceber a existência de um complexo universo simbólico, denominado pelo povo de terreiro como Jurema. Um universo completamente desconhecido para o mundo exterior dos terreiros e praticamente não estudado por pesquisadores. Após a conclusão do projeto, resolvi me dedicar ao estudo do culto da jurema, dando início à minha inserção no tema de pesquisa sobre as religiões afro-brasileiras, mais precisamente sobre o culto da jurema. O primeiro passo foi retomar o contato com Babá Karol e passar a frequentar sua casa e os rituais. A partir dele fui fazendo outros contatos com juremeiros mais antigos da cidade: Geraldo Guedes, Geraldo do Caboclo, Rivaldo Macedo, José Clementino, Olívia Muniz, Joãozinho de Iemanjá, entre outros.

A existência de um conhecimento acumulado sobre o campo das religiões afro-brasileiras na cidade de Natal, mas também a percepção das dificuldades dos sujeitos religiosos de praticarem suas crenças, de se fazerem presentes no universo exterior ao terreiro, associado a questões mais amplas sobre o racismo e preconceito vividos pela população negra na sociedade brasileira e, fundamentalmente, a ausência do enfrentamento dessas questões no espaço escolar, levou-me a pensar um projeto de extensão voltado para a rede pública de ensino. 
O Projeto de Extensão "Antropologia no ensino fundamental: a cultura afro-brasileira", realizado no período de 2001 a 2002, partia do princípio de que a escola deveria ser um espaço de reflexão e vivência da pluralidade cultural, contribuindo para a valorização das culturas, o respeito à diversidade cultural e a ampliação dos conhecimentos.

Durante dois anos seguidos, o projeto esteve em catorze escolas da rede pública de ensino e em seis espaços culturais da cidade de Natal, atendendo a uma demanda existente no universo escolar dos níveis fundamental e médio, composto por um total em torno de vinte mil pessoas. Durante o andamento do projeto, foi possível observar e registrar alguns pontos significativos referentes ao universo escolar. Primeiro, em relação à temática da cultura afro-brasileira, praticamente ausente dos conteúdos curriculares; quando existia, se limitava a reproduzir dados históricos contidos nos livros didáticos, como a abolição da escravatura. Os professores e demais membros da equipe pedagógica das escolas desconheciam o documento dos PCNs - Pluralidade Cultural. É bom lembrar que, somente em 2003, portanto, o projeto já tinha encerrado suas atividades, é que o governo federal aprovou a Lei 10.639/2003, que trata do ensino de história e cultura afro-brasileira nas escolas. Observamos também a escola como um espaço de disputas e conflitos, em que ações conduzidas por religiosos protestantes se faziam presentes, interferindo na condução das atividades pedagógicas da escola. Assim, nem todos os professores aderiram ou foram simpatizantes com o projeto; alguns deles nem sequer permitiam que seus alunos participassem das atividades programadas.

Outro projeto que considero importante relatar neste memorial é Religiosidade na Cidade: a umbanda na Zona Norte de Natal, realizado com financiamento do $\mathrm{CNPq}$, no período de 2003 a 2009. O projeto dá continuidade às pesquisas que vinha realizando no campo das religiões afro-brasileiras em Natal, gerando algumas ações e produtos ${ }^{19}$.

As pesquisas realizadas anteriormente demonstravam a existência de um processo de expansão das religiões afro-brasileiras, especificamente na região denominada de Zona Norte, correspondendo a um percentual de $46,51 \%$ do total de 329 terreiros de umbanda existentes na cidade. Os dados disponíveis indicavam que a realidade era fruto do processo de expansão urbana vivido na cidade nas últimas décadas. A partir dessas constatações, busquei entender em que direção caminha essa expansão religiosa e que forma foi adquirindo sua prática, procurando elaborar um quadro sobre a caracterização da umbanda em Natal, principalmente no que se refere aos aspectos da concepção religiosa, doutrinária, os cultos e as práticas rituais, possibilitando analisar a dinâmica religiosa umbandista, as transformações mais significativas e as relações estabelecidas no campo religioso.

Até o final da década de 1970, a maior concentração de terreiros em Natal está nas áreas urbanas de mais densidade habitacional, os bairros que se inserem na linha histórica do processo de construção urbano-espacial da cidade $^{20}$, além de também serem reconhecidos pela população como espaços populares e mantenedores das tradições culturais. No entanto, a partir de 1980, a expansão horizontal da política habitacional, inicia o processo de expansão urbana da cidade de Natal e da região Zona Norte, fazendo gradativamente desaparecer suas áreas rurais. Como consequência, a cidade passou a atrair contingentes populacionais do interior do estado, em busca dos empregos ofertados, concentrando na Zona Norte, nessa fase inicial, uma população de baixa renda e a dominância de uma paisagem residencial ${ }^{21}$.

O recente processo de expansão urbana da cidade, conforme referido anteriormente, tem consequências para a religião afro-brasileira, em especial 
dando nova configuração à sua distribuição espacial na cidade. Todavia, essas transformações vão além da espacial, por abarcar aspectos relacionados à prática, como formas de cultuar, ritualizar e constituir outras relações e redes.

No início do trabalho de campo do projeto "Religiosidade na cidade" escuto pela primeira vez o relato sobre intolerância religiosa. Lindaura Martins dos Santos Araújo, yalorixá do Ilê Axé Iodu Bolocú Ayê (Conjunto Santarém), relata que durante o toque semanal jogaram pedra no telhado do salão; ato que será repetido em sua casa e em muitas outras nas diferentes regiões da cidade. Outro modo de intolerância vai também ganhar forma. Na mesma época, a yalorixá Ivanete Firmino, do Ilê Axé Forumbê Obai Deli (Loteamento José Sarney), comunica que suas atividades ritualísticas foram paradas até poder atender as solicitações da SEMURB, ou seja, fazer adaptação das paredes para acústica, "colocando espuma e caixa de papelão de ovo", conforme ela me relatou. Agora, os contornos e estratégias da intolerância não estão mais limitados ao espaço da rua e relações comunitárias, mas passam também a ocupar os espaços institucionais públicos.

Em meio a essas e muitas outras questões que o campo aponta, tenho procurado seguir uma agenda de pesquisa pautada pelo compromisso que se concretiza em atitudes de discussão com o grupo sobre as questões que me interessa como estudo e as que interessam a eles, como também assumindo uma postura ao compartilhar com eles questões que dizem respeito específico ao grupo religioso. Talvez seja significativo exemplificar através de uma, entre tantas situações em que fui envolvido, ao atender ao chamado de lideranças de terreiros. A referência específica diz respeito ao convite do babalorixá Jeová Brasil para participar de uma reunião em seu terreiro, que contou com a presença de outros sacerdotes, do presidente da Federação, da minha própria presença (representando a universidade, segundo seu entendimento) e de sua comunidade religiosa. $\mathrm{O}$ encontro teve como objetivo apresentar um documento escrito, assinado pelo babalorixá e dona Marlene, viúva de Babá Karol, no qual autoriza o Pai Jeová Brasil a responsabilidade de coordenar e responder pelo acervo de Babá Karol, inclusive a "divulgação de informações" sobre o referido babalorixá falecido.

Passados alguns meses, as situações estão colocadas, à espera de ações ou reflexões. Retomei o contato com Pai Jeová Brasil visando à criação de um projeto para estudo do acervo de Babá $\mathrm{Karol}^{22}$. De todo modo, além da possibilidade citada, que aponta para reflexões que nos limites deste texto não são possíveis desenvolver, tenho procurado encontrar espaços para combater a intolerância religiosa, como também criar formas que possam dar visibilidade aos terreiros e seus representantes, a religião, enfim.

\section{CULTURAS POPULARES: APOSTA, HORIZONTES DE POSSÍVEIS}

O Grupo de Estudos Culturas Populares surgiu em 2000com o objetivo de criar um espaço institucional que pudesse congregar alunos interessados em discutir e refletir sobre questões que permeiam a complexa temática das culturas populares, ou seja, compreender como as diferentes formas das culturas populares se produzem, criativamente, na sociedade contemporânea, estimulando alunos da graduação e pós-graduação à realização de pesquisas nesse campo temático.

A proposta se estrutura a partir da existência de duas linhas de pesquisa: Manifestações culturais: produtos e processos; Religiosidade. Na pri- 
meira linha, os temas dos trabalhos abarcam o campo das formas de expressão da cultura, como teatro, música, artesanato, dança, enquanto que, no campo da religião, tem se concentrado basicamente em torno do tema do catolicismo popular e religiões afro-brasileiras.

A estratégia do trabalho é composta por atividades permanentes, como os encontros de estudos, e, as atividades eventuais - os seminários. Os encontros vêm ocorrendo mensalmente, desde a sua criação, alternando-se entre estudos de textos relevantes para a temática, a apresentação de comunicações e as oficinas de pesquisa. Durante os primeiros anos, a atenção foi centrada sobre textos que propiciassem a reflexão do conceito cultura popular e a compreensão do processo histórico de sua construção como categoria de análise (Peter Burke, E.P. Thompson, Mikhail Bakhtin). As discussões ampliaram-se, gradativamente, para contemplar textos referentes à memória, à tradição e poéticas da oralidade, abarcando autores como Alfredo Bosi, Gerd Bornheim, Walter Benjamin, Néstor Garcia Cancline, Stuart Hall, Homi Bhabha, Paul Zumthor.

Assim, do ponto de vista do conteúdo, tem sido enfatizado o conceito de tradição e sua relação com memória, narrativa, oralidade, performance, tanto quanto a concepção de etnografia como experiência, compreensão e diálogo entre os modos diferentes de ver o mundo, adotando um viés de construção do conhecimento que privilegia uma abordagem de ciência aberta e interdisciplinar, incorporando múltiplas formas de saberes e operando com modos mais híbridos de construção do pensamento, o simbólico e o racional, a cultura científica e os saberes da tradição. O que estou querendo ressaltar é a perspectiva de pensar determinadas manifestações culturais e processos sociais como mundos em movimento, e não um lugar fixo ou um conjunto de objetos estável, mas como processos nos quais estão incluídas concepções de permanência e transformação, de paradoxos e extremos como caminhos que leva do caos à ordem, conforme ensinam as visões dos autores estudados.

Entre as atividades eventuais, os seminários têm se destacado no âmbito da UFRN, sobretudo por seu conteúdo e por sua perspectiva epistemológica de dialogar com outras narrativas e compartilhar saberes. Trata-se da presença de mestres da tradição que têm participado através de apresentações de suas performances culturais e de comunicações em que compartilham seus saberes com professores e alunos da universidade. Seguindo essa atitude ética, pelas salas da universidade passaram o Mestre Geraldo, do coco de Zambê de Tibau do Sul; o Mestre Severino, do coco de roda de Alcaçuz; o Mestre Correa, dos Congos de Calçola de Ponta Negra; o Mestre Chico Daniel, Raul do Mamulengo e Seu Felipe de Riachuelo, brincantes do João Redondo; Mestre Clemente, dos Caboclinhos de Ceará Mirim; Mestre José, do boi de reis de Parnamirim, todos brincantes produtores das culturas populares, "intelectuais - estejam eles imersos nas culturas tradicionais ou inseridos nas instituições universitárias se ocupando da edificação da cultura científica". (ALMEIDA, 2010, p. 50).

A perspectiva adotada pelo Grupo pode também ser exemplificada no projeto de produção do CD Pontos de Jurema, realizado em parceria com a Fundação Cultural Capitania das Artes (2008). Tendo como ponto de partida a perspectiva dos religiosos sobre a ideia de tradição, conforme apreendida por eles no universo religioso da jurema, foi solicitado que gravassem os pontos cantados escolhidos por cada grupo participante. $\mathrm{O}$ resultado foi um produto com vinte e nove faixas contendo uma sequência que incluiu pontos de abertura e fechamento das mesas de jurema; pontos para as entidades espirituais; pontos considerados significativos para algumas das casas religiosas participantes, etc. Mais uma vez, procurei priorizar a participação dos velhos juremeiros da cidade, propiciando a gravação da voz de Babá Karol, Geraldo Guedes, Geraldo 
do Caboclo e José Clementino, contribuindo para a existência de registro para a memória e patrimônio cultural desse grupo religioso.

Desde a criação do Grupo de Estudos Culturas Populares relações foram sendo estabelecidas com outros grupos, desenvolvendo vínculos institucionais através de eventos, organizações de grupos de trabalhos, pesquisas conjuntas e demais trocas e intercâmbios ${ }^{23}$.

Em 2008, dois projetos foram desenvolvidos a partir de solicitação de órgão externo. O primeiro deles foi o Projeto Registro do Mamulengo como patrimônio cultural do Brasil, aprovado pelo IPHAN e coordenado pela Associação Brasileira de Teatro de Bonecos e pelo Departamento de Artes Cênicas da UnB. O projeto tinha como objetivo produzir conhecimento e documentação sobre o mamulengo, com vista ao seu registro e reconhecimento como patrimônio cultural do Brasil. A outra parceria realizada foi com o Centro Nacional de Folclore e Cultura Popular (Ministério da Cultura) através do Projeto Diagnóstico para implantação do Programa de Promoção do Artesanato de Tradição Cultural, cuja proposta tinha como objetivo compreender a produção artesanal do labirinto e da renda de bilros nas comunidades de Campo de Santana e Alcaçuz, no município de Nísia Floresta - $\mathrm{RN}^{24}$. Mais recentemente, em parceria com o SEBRAE-RN e Fundação Cultural Capitania das Artes foi executado o projeto do mapeamento e estudo do patrimônio imaterial da cidade de Natal, envolvendo vários alunos da graduação de Ciências Sociais.

O Grupo de Estudos é fundamentalmente dedicado à reflexão sobre os processos de pesquisa e deve ser compreendido como um espaço de formação em sua ampla dimensão - teórico-metodológica, ética, política. O cotidiano do processo de aprendizagem inclui ações coletivas, materializadas, por exemplo, em suas publicações (ASSUNÇÃO, 2004; 2012; 2013), sem abrir mão de construir uma agenda que abarque o diálogo e o compromisso de trabalho com o grupo estudado. Para além da construção de um conhecimento científico referente à compreensão do mundo das culturas, busca-se seguir uma antropologia que assuma um envolvimento com os grupos estudados, semelhante à preocupação de Stuart Hall (2003) de fazer dialogar uma teorização complexa e sofisticada com as demandas de segmentos sociais, manter uma agenda política, ou seja, como demonstra o referido autor, o trabalho de elaboração e produção da cultura, em todos os âmbitos, é de interesse público, político.

\section{ÚLTIMAS PALAVRAS}

Todo memorial é parcialmente uma expressão de uma trajetória de vida intelectual. Relendo tudo o que escrevi até aqui, reconheço algumas marcas que me impregnaram de uma forma mais essencial ou que me traçaram, que constituíram em traços de um esboço de vida acadêmica nutrido pela paixão de conhecer. Daí o título deste memorial. Quais são esses traços predominantes da imagem que procuro assumir provisoriamente na minha caminhada acadêmica?

Com humildade, mais rememorando tudo o que foi experimentado por mim, reconheço que tentei ao longo desses anos, trilhas, caminhos, veredas e bifurcações que, por vezes, reconheço na tatuagem de vida da minha mãe; por vezes, na minha curiosidade e estilo aventureiro de percorrer espaços para os quais eu não tinha mapa a priori; por vezes, na obstinação em desafiar a mim próprio, adentrando em culturas e simbologias tão distintas da vida citadina; por vezes, me fazendo um leitor itinerante de histórias imemoriais que procurei resgatar como um arqueólogo das constelações imaginárias. 
Reconheço, com humildade, repito, duas matrizes como sendo a substância de minha trajetória. Em primeiro lugar, a busca por terras desconhecidas nos anos de 1970, quando fui em direção a cidades do sul do país, parece ter se desdobrado na minha permanente viagem por territórios de pesquisas diversas e complementares. Mário de Andrade foi mais do que um projeto de pesquisa. A trajetória pelos caminhos de Andrade respondia por essa minha permanente paixão por conhecer culturas, valores, diversidades da alma humana.

Em segundo lugar, a perspectiva de valorizar, autorizar e homenagear os conhecimentos de raiz parece estarem consonância e coerência com o desejo de reconhecer nas sabedorias locais as cosmologias universais das culturas, sempre no plural, diversas e ao mesmo tempo unas.

O deslocamento e o desejo por bricolar o universal e o particular podem de alguma forma expressar a minha busca sempre incompleta por uma perspectiva antropológica vinculada a uma ética da humildade e do compromisso com todos os cenários que me foram dados viver na minha vida acadêmica. Consegui? Em parte, sim.

\section{NOTAS}

${ }^{1}$ Resolução n. 136-2014-CONSEPE, de 22 de julho de 2014.

${ }^{2}$ Ainda guardo alguns desses preciosos presentes, como um livro datado de 1964, intitulado "Os mais belos contos de fadas da Índia", publicado pela Editora Vecchi.

${ }^{3} \mathrm{O}$ curso de Ciências Sociais (Bacharelado) da UFRN foi reconhecido conforme Decreto Federal número 77.363 de 01.04.1976.

${ }^{4}$ O Movimento Brasileiro de Alfabetização tinha sido criado em plena ditadura militar com o objetivo de realizar um trabalho visando à erradicação do analfabetismo no país, mas também contribuía para a manutenção de um projeto ideológico (Jannuzzi, 1979). Não tenho como propósito desenvolver uma análise sobre esse projeto educacional, apenas relatar minha inserção em sua ação estadual, que considero ter suas especificidades.

${ }^{5}$ Faziam parte da missão, os professores Tom Miller, Kabengele Munanga, Etienne Samain, Angela Tygel e Clarice Novaes da Mota, com os quais estudei antropologia no final da graduação. No ano seguinte, outros professores foram incorporados, entre eles Roberto Ricardo Ringuelet, Madeleine Richeport e Anita Maria Monteiro.

${ }^{6}$ Entre os autores estudados: Eric Wolf, Maurice Godelier, Maria Isaura Pereira de Queiroz, Francisco Graziano, Paul Singer, Maria Nazaré Wanderley, Moacir Palmeira, Lygia Sigaud, José Sérgio Leite Lopes, Maria Conceição D’Incao, Maria Conceição de Almeida, Nazira Vargas.

${ }^{7}$ O Programa de Pós-Graduação em Antropologia Social da UFRN estava organizado com um elenco de disciplinas, de forma que o aluno podia integralizar créditos em um período de até três anos. Após a realização dos cursos, o aluno submetia-se ao exame de qualificação, para em seguida realizar a pesquisa e o exame final, podendo chegar a cinco anos de curso. Do número mínimo de 33 créditos exigidos, cumpri um programa de 37 créditos com as disciplinas: teoria antropológica, métodos e técnicas de pesquisa antropológica, sociedades camponesas, campesinato brasileiro, antropologia econômica, etnologia brasileira, antropologia urbana, antropologia médica, entre outras.

${ }^{8}$ Uma dessas medidas se efetivou através do registro do projeto de pesquisa "Negros do Riacho: um estudo sobre identidade social" (1985), seguido do projeto "Inventário da população negra escrava no município de Currais Novos, 1755-1888” (1988).

${ }^{9} \mathrm{O}$ detalhamento dessas atividades e demais produção acadêmica pode ser consultado no Sistema de Currículos Lattes-Cnpq.

${ }^{10}$ Um desses eventos que participei, denominado de "A crise da razão", organizado pela FUNARTE em 1995, contou com conferências de cientistas e filósofos brasileiros e, entre os estrangeiros: Jacques Rancière, Gérard Lebrun, Michael Lowy, Claude Lefort. No evento de 1998, “A outra margem do ocidente", pude ouvir Patrick Menget, Serge 
Gruzinski, Philippe Descola, entre outros.

${ }^{11}$ A apresentação e exame final da tese "O reino dos encantados, caminhos. Tradição e religiosidade no Sertão nordestino” ocorreu em maio de 1999. Nesse mesmo ano, o trabalho recebeu a Menção Honrosa do Prêmio Sílvio Romero (Ministério da Cultura-FUNARTE). Em 2006, a tese foi publicada pela Pallas Editora (Rio de Janeiro), com o título "O reino dos mestres. A tradição da jurema na umbanda nordestina". Em 2010, uma reimpressão do livro foi produzida pela editora.

${ }^{12}$ Como vice-chefe do Departamento de Antropologia, participei, junto com a professora Anita Monteiro, dos quatro primeiros anos de sua administração. Em seguida, assumi o cargo de chefe do departamento e, novamente, a vice-chefia, perfazendo um total de dez anos ininterruptos participando ativamente na condução do departamento de antropologia da UFRN.

${ }^{13}$ Gostaria de ressaltar que entre os alunos bolsistas que participaram da iniciação científica, dois deles foram premiados como "o melhor trabalho do ano na área de ciências humanas": Rafaela Menezes Ramos, em 2003, bolsista do "Projeto Umbanda e Sociedade" e Marcos Queiroz, em 2005, bolsista do "Projeto Religiosidade na Cidade".

${ }^{14}$ A maioria está inserida em instituições públicas de ensino, como a UFRN, UERN, UEPI, UEBA, UFSE, UFPB, UFPE, UFSA, UNILAB, os Institutos Federais de Educação dos Estados do RN, Paraíba e Ceará.

${ }^{15}$ O Fonds Documentaire Paul Zumthor está localizado na Biblioteca de Livros Raros e Coleções Especiais da Université de Montréal e abarca o acervo referente às publicações do escritor, composto por monografias (89), capítulos de livros (36), artigos em periódicos (139) e outros documentos como cadernetas e correspondências.

${ }^{16}$ Participo de uma rede que inclui pesquisadores do Brasil, Portugal, França, Canadá, dedicados ao estudo da obra Zumthor. Em 2015, a convite da Université Paris Nanterre La Défense participo do Colloque International Poétique de Paul Zumthor (1915-2015). Recentemente organizei com a professora Beliza Áurea de Arruda Mello o livro "Paul Zumthor, memórias das vozes" (2018).

${ }^{17} \mathrm{O}$ convênio tinha como proposta a realização de relatórios antropológicos visando à identificação e delimitação de seis territórios de remanescentes das comunidades de quilombo, conforme Artigo 68 do Ato das Disposições Constitucionais Transitórias da Constituição Federal de 1988 e Decreto 4887, de 20 de novembro de 2003. Além de coordenar os dois convênios firmados entre as instituições, assumi o relatório referente à comunidade quilombola do Jatobá (Assunção, 2009b).

${ }^{18}$ Sobre os processos cívil, que em seu conjunto denominei de "Autos da Cafunga", referem-se a ações de liberdade, processos judiciais nos quais os escravos, por intermédio de seus curadores, procuram conseguir a alforria junto aos seus senhores pelos mais variados motivos. Esses processos são marcados por diferentes formas de ações e lutas por liberdade protagonizadas por personagens e densas histórias, que a historiografia potiguar parece não ter demonstrado muito interesse.

${ }^{19}$ Projeto Cartografia dos Terreiros de Natal, iniciado em 2010 através do mapeamento dos terreiros de Natal, procurando organizar os dados disponíveis, atualizá-los e dar visibilidade às informações existentes, geradas ao longo das pesquisas realizadas. A proposta se vincula a um projeto mais amplo coordenado pelo Programa Terreiros do Brasil (SEPPIR) do governo federal. Um acervo virtual foi produzido por intermédio da criação de uma página na internet hospedada no site do Centro de Ciências Humanas, Letras e Artes da UFRN - www.cchla.ufrn.br/mapeamentodosterreirosdenatal.

${ }^{20}$ É nessa área urbana, especificamente a Zona Leste, por exemplo, que se concentra a maior quantidade de terreiros - 149, que corresponde a 50,34 \% do número total. No primeiro levantamento estatístico realizado (1985), a região urbana Zona Norte aparece com 33 terreiros (11,15\% do total). Considerando que nesse total estão incluídos os terreiros dos distritos de Igapó (23) e Redinha (06), teremos, portanto, apenas dois terreiros da recente área de expansão urbana da cidade (Zona Norte), formada pelos denominados conjuntos habitacionais.

${ }^{21}$ Tomando os dados estatísticos, é possível afirmar que, em menos de 10 anos, na década de 1980, os terreiros na Zona Norte da cidade de Natal têm um crescimento de 3,38 \% para 46,51 \% na relação com o número total de terreiros existentes na cidade. Existe um crescimento das religiões afro-brasileiras na Zona Norte de Natal, que acompanha a expansão urbana na referida região.

${ }^{22}$ O projeto foi registrado em 2017, na Pró-Reitoria de Pesquisa da UFRN, com o título 
"Memória e patrimônio religioso afro-brasileiro" e embora alguns acervos de terreiro estejam incluídos, como o de Babá Karol, a primeira fase de execução do projeto, foi dedicada ao acervo religioso do Centro Humilde de Caridade São Lázaro (Bairro das Quintas), fundado pelo babalorixá José Barroso dos Santos.

${ }^{23}$ Entre os grupos, citamos o Projeto Nação Potiguar (Fundação Hélio Galvão), o Laboratório de Estudos da Oralidade (UFPB), o Grupo de Pesquisa Memória e Imaginário das Vozes e Escrituras (UFPB), o Grupo de Estudos e Pesquisas em Etnomusicologia (UFPE) e o Grupo de Estudos Culturais (UERN).

${ }^{24}$ A primeira parceria contou com a participação dos alunos de pós-graduação Ricardo Canella e Maria das Graças Cavalcanti Pereira, enquanto que na segunda, o participante envolvido foi Nilton Xavier Bezerra, aluno do PPGAS.

\section{REFERÊNCIAS}

ALMEIDA, Maria da Conceição de. Complexidade, saberes científicos, saberes da tradição. São Paulo: Editora Livraria da Física, 2010.

ANDRADE, Mário. O turista aprendiz. São Paulo: Duas Cidades, 1983.

ASSUNÇÃO, Luiz. (Org.). Cultura Popular. Revista Vivência, n. 27, jan./jun. Natal: UFRN-CCHLA, 2004.

. O reino dos mestres: a tradição da jurema na umbanda nordestina. Rio de Janeiro: Pallas, 2006.

. Os negros do Riacho: estratégias de sobrevivência e identidade social. Natal: Edufrn, 2009a.

. Jatobá: ancestralidade negra e identidade. Natal: Edufrn, 2009b.

. (Org.). Da minha folha: múltiplos olhares sobre as religiões afro-brasileiras. São Paulo: Arché, 2012.

. (Org.). Um Barco: experiências etnográficas e diálogos com as culturas populares. Natal: Edufrn, 2013.

ASSUNÇÃO, L; MELLO, Beliza Áurea de A. (Orgs.). Paul Zumthor, memórias das vozes. São Paulo: Arché, 2018.

BAKHTIN, Mikhail. Marxismo e filosofia da linguagem. São Paulo: Hucitec, 1986.

. Estética e criação verbal. São Paulo: Martins Fontes, 1992.

BARTH, Fredrik. Los grupos étnicos y susfronteras. México: Fondo de Cultura Econômica, 1976.

BASTIDE, Roger. Brasil, terra de contrastes. Rio de Janeiro: Difel, 1978. . As religiões africanas no Brasil. São Paulo: Pioneira, 1989.

BHABHA, Homi K. O local da cultura. Belo Horizonte: Ed. UFMG, 1998.

BOURDIEU, Pierre. A ilusão biográfica. In: AMADO, Janaína e FERREIRA, Marieta de M. (Orgs.). Usos \& abusos da história oral. Rio de Janeiro: Editora da Fundação Getúlio Vargas, 1996.

CÂNDIDO, Antônio. Os parceiros do Rio Bonito: estudo sobre o caipira paulista e a transformação dos seus meios de vida. São Paulo: Duas Cidades; Editora 34, 2001.

CARDOSO DE OLIVEIRA, Roberto. Identidade, etnia e estrutura social.

São Paulo: Pioneira, 1976.

COUTO, Mia. Pensatempos. Textos de opinião. Lisboa: Editorial Caminho, 2005.

FERREIRA, Jerusa Pires. O universo conceitual de Paul Zumthor. Revista do $I E B$, n. 45. São Paulo: USP, set. 2007. 
FREIRE, Paulo. Pedagogia do oprimido. 11. ed. Rio de Janeiro: Paz e Terra, 1982.

GADAMER, Hans-Georg. Verdade e método I: traços fundamentais de uma hermenêutica filosófica. Petrópolis: Vozes, 2012.

GEERTZ, Clifford. A interpretação das culturas. Rio de Janeiro: Zahar, 1978.

HALL, Stuart. Da Diáspora: identidades e mediações culturais. Belo Horizonte: Editora UFMG; Brasília: Representação da Unesco no Brasil, 2003.

JANNUZZI, Gilberta Martino. Confronto pedagógico: Paulo Freire e Mobral. São Paulo: Ed. Cortez, 1979.

MERLEAU-PONTY, Maurice. Fenomenologia da percepção. Tradução de Carlos Alberto Ribeiro de Moura. São Paulo: Martins Fontes, 1994.

MOURA, Margarida Maria. Os herdeiros da terra: parentesco e herança numa área rural. São Paulo: Editora Hucitec, 1978.

PEREIRA, João Batista Borges. Estudos antropológicos das populações negras na USP. Revista de Antropologia, v. 24. São Paulo: Edusp, 1981.

PRANDI, Reginaldo. (Org.). Encantaria brasileira: o livro dos Mestres, Caboclos e Encantados. Rio de Janeiro: Pallas, 2001.

PRIGOGINE, Ilya. O fim das certezas: tempo, caos e as leis da natureza. São Paulo: Editora da Unesp, 1996.

VARGAS, Nazira Abib Oliveira. História que o povo conta: opressão e sobrevivência. Recife: FUNDAJ, Massangana, 1987.

ZUMTHOR, Paul. Introdução à poesia oral. São Paulo: Hucitec, 1996. 